\title{
Minimum inhibatory Concentration of the combination of Quaternary ammonium compound with Ethylenediaminetetra- acetic acid (EDTA) towards hand isolated Staphylococcus epidermidis
}

\author{
Dyah Ika Maria, \\ Department of Oral Biology Faculty of Dentistry Universitas Padjadjaran
}

\begin{abstract}
The aim of this study was to determine the Minimum Inhibitory Concentration (MIC) of the combination of Quaternary ammonium compound with Ethylenediaminetetra-acetic acid (EDTA) towards hand isolated Staphylococcus epidermidis for preventing the cross infection. The Minimum Inhibitory Concentration was determined based on a serial dilution method in $1 / 1000,1 / 2000,1 / 4000,1 / 8000$, $1 / 16000,1 / 32000,1 / 64000,1 / 128000$ concentration with two repetition. The result showed that the $1 / 4000$ concentration of the combination of Quaternary ammonium compound with Ethylenediaminetetraacetic acid was the MIC. In conclusion, the combination of Quaternary ammonium compound with Ethylenediaminetetra-acetic acid had an antibacterial effect towards Staphylococcus epidermidis with the MIC in 1/4000 concentration.
\end{abstract}

Key words: Minimum inhibatory Concentration of the combination of Quaternary ammonium compound with Ethylenediaminetetra-acetic acid (EDTA) towards hand isolated Staphylococcus epidermidis

\section{INTRODUCTION}

Dentist has high risk in getting infectious disease from patient whom he or she takes care of. The biggest risk for health care workers who get direct contact with blood and body fluids is the transmission of Hepatitis B (HBV) and Human Immunodeficiency Virus or HIV. ${ }^{1}$ This infection transmission could happen through direct or indirect contact via contaminated tools or surfaces. ${ }^{2}$

Hand is an important source of microorganism spreading $^{3}$, Hand hygiene is an important personal hygiene way for each individual, especially for health care workers in medicine and dental field.
That becomes a primary preventive procedure for disease-spreading. ${ }^{3}$

Staphylococcus epidermidis is normal organism in human skin, respiratory tract and gastrointestinal tract. These bacteria could cause disease which related with implant and prosthetic device used especially in babies, geriatric and immunocompromised patients. ${ }^{4}$ Staphylococcus epidermidis could cause serious infection if it gets into epidermis and mucous during hospitalization. ${ }^{5}$

A method which has been proved came in useful in controlling nosocomial infection is increasing health care workers' knowledge about Universal Precautions, which is a controlling way 
to minimize blood and body fluid exposures from all patients, without bother about their infection status. The foundation of universal precaution is right hand-washing, use of personal protector, disinfection and prevention of needle-stick injury, in order to avoid microorganism transmission in blood and body fluids. ${ }^{6}$

Cation detergent, which represented by quaternary ammonium (e.g. benzalkonium chloride) for years, used as solution in cold sterilization process. $^{7}$ Cation detergent could decrease surface voltage and impair bacterial cell membrane. ${ }^{8}$

Quaternary ammonium compound works more effective on Gram-positive bacteria rather than Gram-negative bacteria. This compound is bactericidal by bacterial enzyme inactivation, protein denaturation and bacterial cell membrane impairment. ${ }^{9,10}$ Quats also has fungicidal, amoebocidal and virucidal effects in fighting enveloped virus. ${ }^{11}$ Quaternary ammonium used as antiseptic for skin and disinfectant. ${ }^{12}$ Ethylenediaminetetra-acetic acid (EDTA) is an efficient in vitro chelator for bivalent and trivalent metal. ${ }^{13}$ (Katzung, 2004). EDTA could be used to prevent agglutination. EDTA was largely used as chemical rather than drug. ${ }^{14}$ (Meyers, et al., 1974).

EDTA has an important role in various antibacterial activities fighting Gram-negative bacteria but not for Gram-positive bacteria. EDTA caused increasing in permeability of cell outer layer from Gram-negative bacteria. ${ }^{15}$

\section{METHODS}

This research was performed based on laboratory examination method i.e. by testing effectiveness of combination of quaternary ammonium compound with EDTA in inhibiting growth or killing Staphylococcus epidermidis by determining minimum inhibitory concentration.

This research was conducted in microbiology laboratory in Dentistry Faculty of Padjadjaran University from April till July 2007.

Experiment bacteria used were isolated from hands of five university student from Dentistry Faculty of Universitas Padjadjaran in the following way: after operator finished giving treatment to patient, research subjects' hand were washed by correct hand-washing technique by using 100 $\mathrm{ml}$ of aquadest, then the rinsed water were put in sterile Petri dish. These rinsed aquadest used as research object which immediately need to be taken as many as $0,1 \mathrm{ml}$ then cultivated and spread evenly in Blood Gelatin Plate (BGP) using loop. Proliferated BGP were hatched in incubator for 24 hours in $37^{\circ} \mathrm{C}$.

Identification of experiment bacteria was conducted based on characteristic and morphology of bacteria colony which grow in BGP i.e. colony which has round shape, dome-shaped, white-colored, and do not lyses the blood. After that, the Gram stained is being conducted then microscopic examination is performed.

After being incubated for 18 to 24 hours, biochemical test was conducted, that is catalysation and coagulation test. Catalysation test was used to distinct Staphylococcus and Streptococcus by dropping $\mathrm{H}_{2} \mathrm{O}_{2} \quad 3 \%$ solution to bacteria suspension which suspected to be Staphylococcus. If the catalysation test is positive proved by appearance of air bubble, then moved forward to coagulation test. Coagulation test used to distinct Staphylococcus aureus with other Staphylococcus by using blood serum mixed with bacteria suspension. If the serum did not coagulate in the coagulation test, perform Novobiocin sensitivity test to the bacteria.

After that, serial dilution was performed in order to know the minimum inhibitory concentration (MIC) of combination of quaternary ammonium compound with EDTA towards experiment bacteria

\section{RESULT AND DISCUSSION}

Colony which suspected to be Staphylococcus genes has characteristic of round-shaped, soft, protrude, grey to white-colored and do not lyses blood. Gram-stained result on bacteria which has Staphylococcus colony characteristic showed illustration of coccus shaped, purple-colored (Gram-positive characteristic), arranged in unorganized groups like grapefruit with diameter about $1 \mu \mathrm{m}$.

Biochemical test like catalysation test resulted in formation of air bubble the moment that bacterial suspension is being dropped with $\mathrm{H}_{2} \mathrm{O}_{2} 3 \%$ solution. Staphylococcus produces catalysation, 
which could change hydrogen peroxide into water and oxygen. ${ }^{4}$

Coagulation test using blood serum did not show any coagulation in suspension, so that it is called negative coagulation.

Sensitivity test towards Novobiocin showed an inhibitory area around the Novobiocin disc in about $18 \mathrm{~mm}$, which showed that the bacteria are sensitive towards Novobiocin. Based on the result obtained, that colony could be identified as Staphylococcus epidermidis.

Result of sector cultivation in serial dilution on BGP from each concentration resulted that $60 \%$ of the bacteria growth with minimal number started on the third pipe which is in concentration 1/4000 (Tab.1).

Observation result on sector cultivation showed that there was an influence in concentration difference of combination quaternary ammonium compound with EDTA towards bacterial growth in sector. The smaller the concentration of combination from quaternary ammonium compound with EDTA, then the bacterial growth is higher. Rate of concentration is inversely proportional with bacterial growth.

Obtained MHC was very low, which means that combination of quaternary ammonium compound with EDTA is a fine disinfectant. Other than that, combination of quaternary ammonium compound with EDTA is also more economic.

Cell wall of Staphylococcus formed by peptidoglycan and teicoat acid. These two materials act as effective barrier for antiseptic and disinfectant entries. Substance with high molecule weight could destruct cell wall on Staphylococcus genes and vegetative Bacillus spp. These things which cause the bacteria become sensitive to various antimicrobial included quaternary ammonium and chlorhexidine. ${ }^{16}$

The antibacterial function of quaternary ammonium compound related with its surface activities. Hydrophobic alkyl chain benefit the contact with bacteria cell wall which is lypophilic, due to membrane permeability changes, essential cell content could also come out. ${ }^{17}$

EDTA could cause lypopolysacharide to come out from Pseudomonas aeruginosa cell wall. EDTA could also inhibit biofilm formation in bacteria. ${ }^{18}$

EDTA has the ability to bind calcium, magnesium and some other metal ion so that they could neutralize water from the intruder substance. These things made possible for quaternary ammonium compound to work more effectively. ${ }^{19}$ Quaternary ammonium compound binds with phospholipids on bacteria cell membrane the react with the hydrophobic bacteria cell membrane. In low concentration (MIC), interaction with bacteria cell membrane could cause increasing of surface voltage and decreasing of membrane fluidity in such a way that the membrane lost its osmoregulation and physiology function. In higher concentration, quaternary ammonium destruct cell with cell membrane dissolved, which caused leak out of all content in bacteria cell. ${ }^{20}$

Concentration of the same used solution combination of quaternary ammonium compound with EDTA increased efficiency in fighting Gramnegative and Gram-positive bacteria if compared to EDTA-using, dan still work effectively in hard water. ${ }^{18}$

\section{CONCLUSION}

Based on research result, we can conclude that: Combination of quaternary ammonium compound with EDTA has antibacterial capacity toward Staphylococcus epidermidis, Minimum Inhibitory Concentration (MIC) for combination of quaternary ammonium compound with EDTA towards Staphylococcus epidermidis is $1 / 4000$.

\section{SUGGESTION}

Further research need to be conducted to learn about antibacterial effect of combination of quaternary ammonium compound with EDTA towards more Staphylococcus epidermidis and other bacteria sample, especially hand bacteria which could cause nosocomial infection. Used solution concentration suggested for clinical application for hand-washing is $4 \mathrm{x}$ MIC value, which is in $1 / 1000$ concentration.

\section{REFERENCES}

1. Burton GRW, Engelkirk PG. Microbiology for the health sciences. $5^{\text {th }}$ ed. New York: Lippincot. 1996.

2. Bagg J, Mac Farlane TW, Poxton IR, Miller 
$\mathrm{CH}$, Smith AJ. "Essential of microbiology for dental student." New York: Oxford University Press. 1999.

3. Miller $\mathrm{CH}$, Palenik CJ. Infection control and management of hazardous materials for the dental team. Missouri: Elsevier Mosby. 2005.

4. Brooks GF, Butel JS, Morse SA. Medical microbiology. $23^{\text {rd }}$ ed. New York: Lange Medical Book/ Mc Graw Hill 2004.

5. Yao $Y$, et al. Factors characterizing staphylococcus epidermidis invasiveness determined by comparative genomic. 2005. [cited 2007 Jul 20]. Available from:www. Pubmedcentral.nih.gov.htm.

6. [cited 2007 Jul 20]. Available from:http:// www.infeksi .com

7. Yagiela JA, Down FJ, Neidle EA. Pharmacology and therapeutics for dentistry. $5^{\text {th }}$ ed. Missouri: Mosby; 2004.

8. Newman MG, Korman KS. Antibiotic, antimicrobial use in dental practice. Chicago: Quintessence Publishing Co., Inc.; 1990.

9. Tan HT, Kirana R. Obat-obat penting. Jakarta: Elex Media Computindo. 2002.

10. Kayser FH, Bienz KA, Eckert J, Zinkernagel RM. Medical microbiology. Stuttgart: Thieme; 2005.

11. Tortora GJ, Funke BR, Case CA. Microbiology an introduction. $7^{\text {th }}$ ed. USA: Benjamin Cummings; 2001.

12. Ketchum PA. Microbiology concept and application. Canada: John Willey and Son. 1988.

13. Katzung

14. Russel Hugo, Ayliffe's. Principles and practice of disinfection, preservation and Sterilization $4^{\text {th }}$ Ed Massachusetts: Blackwell Publishing. 2004.

15. McDonnel G, Russel D. Antiseptics and disinfectants: activity, action, and resistance. 1999. [cited 2007 Jun 26]. Available from: www.cmr.asm.org.htm.

16. Schunack W, Haake KM. Senyawa obat; Buku pelajaran kimia farmasi. edisi kedua, diperbaharui. Yogyakarta: Gajah Mada University press. 1990.

17. Chiang M, Yao-Chi, Hall LK. Antimicrobial quaternary ammonium compositions with reduced ocular irritation. 2003. [cited 2007 Jun 20]. Available from:http://www. freepatentonline.com.

18. Lawrence CA, Block SS. Disinfection, strerilization, and preservation. Philadelphia: Lea Febiger. 1971.

19. Gilbert P. Polyhexamethylene Bisguanides and Infection Control. 2004. [cited 2007 Agus]. Available from:http://www.tycohealth-com.

20. Cappucino JG, Sherman N. Microbiology: a laboratory manual. San Franscisco: Benjamin Cummings;2002.

21. Samaranayake LP. Essential microbiology for dentistry. $2^{\text {nd }}$ Ed. London: Churchill Livingstone. 2002. 